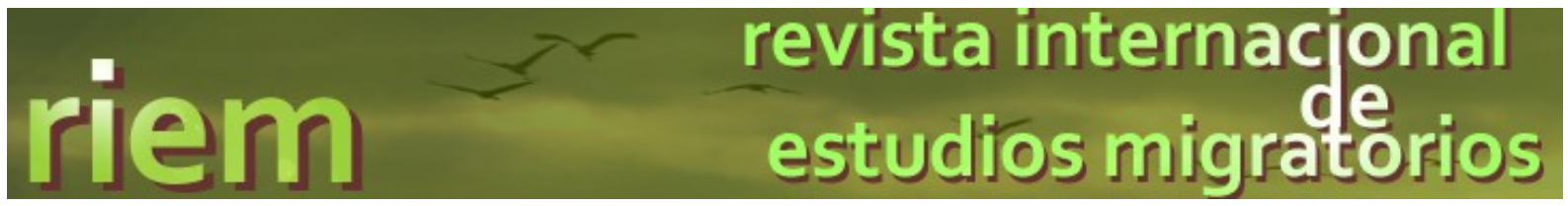

\title{
Return migration policies from a transnational approach: the case of Spain and Colombia
}

Las políticas de retorno desde una perspectiva transnacional: el caso de

España y Colombia

\author{
Clara Piqueras ${ }^{1}$ \\ ${ }^{1}$ Departamento de Sociología, Universidad Autónoma de Barcelona, \\ Barcelona, España
} clara.piqueras@uab.cat

(C) Revista Internacional de Estudios Migratorios. CEMyRI. UAL (España) 


\begin{abstract}
Introduction: At the present time, in a context marked by the economic crisis in Europe and the USA, an expansion of new dynamics of mobility is observed. In this scenario, the phenomenon of return migration has gained increased interest in both the political and academic field. Following a theoretical transnational approach, this article collects and analyses policies and voluntary return programmes promoted by the Spanish and the Colombian governments, considering the way in which return migration is conceived in terms of management and temporality, and identifying the returnees' profile considered in these policies.

Method: The text presents a qualitative analysis of the policies and the main programmes promoted by both countries, being the analysis conducted in two dimensions: types of action towards return migration and type of returnees' profile.

Results: Policies developed from Spain are characterised for being especially targeted to a profile of return migrant that is at risk of being in a vulnerable position or is already experiencing one. They also highlight the imposition of non-entry into Spain to reside for a period of three years, denying, therefore, circular mobility or re-migration. On the other hand, the Colombian government stated in its regulations a broader typology of returnees, however, the programmes developed have focused on selective returned profiles: qualified or entrepreneur returnees.

Conclusion: The analysis of the return migration policies and programmes from Spain and Colombia shows that the actions focus on specific profiles of returnees, not taking into account the variability of situations and factors affecting the return migration. Moreover, there is a lack of coordinated origin-destination management, which results in an absence of transnational management approaches that could bring together resources and target the process from a more holistic point of view.
\end{abstract}

Keywords: return migration policies, return migration, transnational approach, Colombia, Spain 


\section{Resumen}

Introducción: En la actualidad, en un contexto marcado por la crisis económica en Europa y EEUU, se observa una expansión de nuevas dinámicas de movilidad. En este escenario el fenómeno de la migración de retorno ha ido adquiriendo un mayor interés en el ámbito político y académico. A partir de una mirada teórica transnacional, el artículo recoge y analiza las políticas y programas de retorno voluntario impulsados desde España y Colombia, atendiendo al modo en el que se concibe la migración de retorno en términos de gestión y temporalidad, e identificando los perfiles que han sido objetos de dichas acciones.

Método: El texto presenta un análisis cualitativo de la normativa y los principales programas impulsados por ambos países, encontrándose vehiculado el análisis por dos dimensiones: tipo de actuación adoptada ante el retorno; y perfiles objeto de tales políticas.

Resultados: Las políticas desarrolladas desde España se caracterizan por estar dirigidas especialmente a un perfil de migrante en situación o riesgo de vulnerabilidad, destacando asimismo la imposición de no entrada a España para residir en un término de tres años, y negando, por tanto, movimientos circulares o de re-migración. Por su parte, el gobierno colombiano recoge en su normativa una tipología más amplia de retornados, aunque los programas desarrollados se han centrado en un perfil de retornado selectivo: el cualificado o emprendedor.

Conclusión: El análisis de la normativa y programas de España y Colombia en materia de retorno da cuenta de una focalización hacia perfiles de retornados concretos, obviando la variabilidad de situaciones y factores que inciden en el retorno. Por otro lado, se advierte la carencia de una gestión origen-destino coordinada, habiendo una ausencia de planteamientos de gestión transnacionales que permitirían aunar recursos y atender al proceso de manera integral, y no como si de fases aisladas se tratara.

Palabras Clave: políticas de retorno, migración de retorno, perspectiva transnacional, España, Colombia 


\section{Introduction}

Although the issue of return migration has traditionally received little attention from policy-makers and analysts (Ghosh, 2000; King, 2017), in the following years, partly as a result of the changing geopolitical and economic realities in the USA and Europe, an expansion of new dynamics of mobility is observed. In this scenario, the phenomenon of voluntary return migration has gained increased interest in the political and academic fields. The implementation of policies and programmes aimed at return migration has been carried out in the host countries as well as in the countries of origin of migrants, with different actions and objectives of each of the parties. Several authors (Castles, 2006; Mejía \& Castro, 2012; Papademetriou, Sumption, \& Terrazas, 2010) have pointed out how the countries receiving migration have chosen to enhance the return process in a context of economic recession and unemployment, where the debates and the migration policies are more restrictive, and aim to meet the demands of the job market by promoting temporary jobs among the migrant community (Parella, Petroff, Piqueras, \& Aiello, 2015). The most active development of return policies by the governments of the sending countries also revolves around a scenario of crisis and the tightening of immigration rules. On the other hand, some researchers have associated the implementation of these policies with the impact that returnees have on contributing to the country development, given the economic and human resources accumulated during the migratory experience (Moncayo, 2011; Parella et al., 2015).

Academic research has mainly focused on the economic elements of return migration and its consequences with regards to the migrant's countries of origin (Ammasari \& Black, 2001; Ghosh, 2000), but it is not all that common to find studies focusing on the revision of return migration policies and programmes from the perspective of different territories. Because of this, based on a transnational approach, in this article it is considered necessary to tend to the political management of the return from both countries of origin and migratory destination, understanding that there is no rupture between them during the migratory experience or return. The article collects and analyses policies and voluntary return programmes promoted by Spain -as a host country of migration - and the Colombian government -as a country of origin-, considering the way in which return migration is conceived in both scenarios in terms of management and temporality, and identifying the profiles that have been objects of such actions. In this sense, the text refers exclusively to voluntary return, understood as the 
return to the country of origin as a result of a subject personal decision that is not the result of an expulsion order.

Far from aiming to analyse the evaluative assessments directed to the programmes of the actors involved or their effectiveness (impact or numbers of hosts), this text focuses on understanding the way in which different countries approach the phenomenon of return at the political level and what actions are designed to respond to the current migration situation in both scenarios, considering the following analytical dimensions:

- Types of action towards return. Exploring what kinds of initiatives have been developed and their purpose with regards to return management (humanitarian assistance, informative advice and/or training, support in the reintegration process in the country of origin, etc.). The text also aims to analyse the way in which such actions conceive return in terms of temporality (permanent, seasonal, circular) and the level of management applied (unilateral or bilateral intervention, transnational return management).

- $\quad$ Profiles that are the object of return policies. Identify which profiles are listed in the return programmes and return, based on a typology that includes returnees in vulnerable situations, work-related returns or returns with productive projects, and highly-qualified returning migrants (Mármora, 2002; Sánchez Trigueros \& Fernández Collados, 2010).

The text is divided into five sections. The first part presents briefly the methodology followed throughout the paper. The second part exposes the key theoretical and conceptual standpoints on which the analysis of the political actions is framed. This part is followed by a reference to migration in Spain and from Colombia, with the aim of establishing the dynamics of mobility during recent decades and, particularly, after the economic recession. The last section describes and analyses the return policies and programmes driven by the two countries mentioned, concluding the text with an explanation of the conclusions drawn from the analysis.

\section{Method}


As already mentioned, the paper focuses on the review and analysis of the return policies promoted from Spain and Colombia, with the purpose of dealing with the return management both from one destination country (in this case, Spain) and another of migratory origin (in this case, Colombia). It is therefore based on the idea, from the transnational perspective, that the return migration must be addressed from the different territories involved in migration. The aim is to overcome an analysis focused only on a territory, seeking to overcome the methodological nationalism view and avoiding this way a nation-state-centred methodology (Amelina \& Faist, 2012; Wimmer \& Glick Schiller, 2002).

As a result, a qualitative analysis of the legal texts and the programmes promoted from both countries is carried out, from the two analytical dimensions previously mentioned: (1) types of action towards return, and (2) profiles of migrants that are the object of return policies. With regards to the sampling criteria, the paper focuses on the political actions in force since 2007/2008, when the economic crisis in the US and Europe began, until 2015, date in which the last initiative regarding return migration was recorded.

\section{Return migration from a transnational perspective}

There are several theories from which the phenomenon of return migration has been addressed. In this sense, Cassarino (2004) presents an accurate summary of the main return migration theories. On the one hand, the more traditional approaches indicate that the return is a rational and individual evaluation of the wage differential between origin and destination, and those benefits that the subjects could obtain upon return. From these approaches, such as the Neoclassical theory (Todaro, 1969) or the New Economics of Labour Migration perspective (Stark, 1991), the return migration is assumed based on the success/failure dichotomy of the migration experience, referring only to economic elements that motivated the mobility, and simplifying a complex process and the several reasons and profiles of migrants who return to their host country.

On the other hand, the Structural approach seeks to overcome this uni-territorial view of the process by pointing out the importance of the origin-destination context and the need to address the economic, political and social reality at source, as well as the expectations of the returned person (Dumon, 1986; Gmelch, 1980). Although from the several variables considered when it comes to the structural approach with regards to 
the country of origin and destination, the elements taken into account are fundamentally responsive to a macro analysis scale. Striving to overcome these theoretical and analytical scarcities, the Transnational perspective and the Social Network theory insist on relevance of the actions taken by the return migrants themselves, either as agents of transnational practices and bearers of transnational identities (Portes, Guarnizo, \& Landolt, 1999), or as social actors involved in multiple relational ramifications (Massey \& Espinosa, 1997). From both perspectives, the purpose is to overcome the analytical limitations of the approaches that explain the return migration phenomenon focusing only on the economic elements, and on the impact on the country of origin.

What's more, rejecting the linear conception of the migration process, which is typical of the classical view of the phenomenon and based on the current migration context, where the dynamism of the migratory movement and the simultaneity of multilocal social processes stands out (Wimmer \& Glick Schiller, 2002), the transnational perspective raises interesting conceptual challenges in the study of mobility. From this theoretical perspective it can be argued that the mobility of people comprises complex circuits where the return should be treated as one more stage of the migration process (De Haass \& Fokkema, 2010; Rivera, 2009; Sinatti, 2011). Therefore, it is necessary to address the phenomenon from a point of view that deconstructs the classical categories of migration, and which allows us to consider more complex forms of mobility that are excluded from the temporary dichotomous approaches, such as the circular or pendulum migration ${ }^{1}$, or the re-migrations to third countries (Cortes, 2009).

Then again, while the traditional approach sees migration as an event-rupture in the space-time continuum (Cortes, 2009), the transnational perspective refers to it as the set of social processes that link and go beyond geographical, political and cultural borders (Basch, Glick Shiller, \& Szanton Blanc, 1994). It focuses, therefore, on frequent practices and links that are sustained over time across borders. Transfers can be tangible or intangible -economic, social, emotional, cultural or political (Portes et al., 1999) and may be carried out by different actors. In the scientific literature, different forms of transnationalism have been defined depending on who promotes it, distinguishing between the practices driven

\footnotetext{
${ }^{1}$ Circular migration can be referred to as a social process that facilitates the comings and goings of the subjects between the place of origin and destination (Solé, Parella, Sordé, \& Nita, 2016), where there are movements taking place between two spaces featuring pendulum migrants who choose to develop multilocal residential strategies (De Haas \& Fokkema, 2010).
} 
"from below" -activities carried out by the migrants- and "from above" -initiatives promoted by the governments of origin (Guarnizo, 2006b; Portes, 2005).

Practices carried out by governments include, among others, governmental policies that legitimise and promote cross-border connections with compatriots residing abroad. The immediate objective of these practices is the reinstatement or recovery of migrants to the national project. In this sense, Mármora (2002) distinguishes between policies that aim to the symbolic recovery of migrants ("diaspora engagement policies") and those that encourage the physical recovery of their co-nationals living abroad ("return policies"). However, Smith (1999) points out that sometimes the distinction between the two types of policies is not absolute and the states may apply both simultaneously or switch from one to the other.

The initiatives in terms of diaspora engagement policies aim to encourage the participation of migrants in their society of origin ${ }^{2}$. However, Portes, Escobar, and Walton (2006) indicate that these policies generally have been developed due to the growing importance of transnational practices carried out by the migrants themselves. In this sense, many researchers say that diaspora engagement policies respond to instrumental reasons, given that the different states have warned of the impact of skilled migrants, the remittances or the political role of nationals from abroad (Bauböck, 2003; Levitt \& Glick Schiller, 2004).

On the other hand, in relation to the measures developed for return management, understanding these as an incentive and/or complement for the physical return to the country of origin, one can distinguish four types of measures to promote the return: 1) programmes for people in vulnerable situations, 2) programmes aimed at promoting the return focusing on the labour and economic reintegration, 3) actions aimed at recovering skilled human capital, and 4) actions pursuing the resettlement of people who migrated or involuntarily return ${ }^{3}$ (Mármora, 2002; Sánchez Trigueros \& Fernández Collados, 2010). If, as indicated, diaspora engagement policies have been associated with government strategies in terms of development, some authors claim that return programmes in some cases have been carried out in the same terms (Moncayo, 2011). In this sense, Mármora (2002) refers to "positive recovery" in relation to promoting the

\footnotetext{
${ }^{2}$ Levitt \& de la Dehesa (2003) distinguish various forms of attachment promoted by the state, among which is the recognition of rights, state protection, ministerial and consular reforms, policies to attract investment, and symbolic actions to reinforce membership and national identity.

${ }^{3}$ As already indicated, this text won't go into the actions aimed at people who migrated forcibly or involuntary returns as a result of an expulsion.
} 
return of a particular profile of migrants based on the "contributions" that they may make upon their return to the country of origin.

Beyond the categorisation of programmes, in order to overcome dichotomies and partial analysis of the return migration, from the transnational perspective it is fundamental to address the phenomenon in an integral way, considering each of the phases that comprise the process, ranging from the intention of returning (motivation), the decision-making and preparation of the migration (action), to the post-return (reintegration) (Parella, Petroff, Speroni, \& Piqueras, 2017). For this, policies relating to returning migrants should be present both in the destination and host country. Understanding the return as a stage of the migratory cycle, this new territorial movement maybe requires organisation or a preparedness process (Cassarino, 2004), where it could be essential for the migrants to receive information about the situation in origin and to have the capability to organise and mobilise economic and social resources for experimenting an optimal reintegration process in origin (Cobo, 2008) ${ }^{4}$.

In relation to the post-return stage, a key aspect is to attend to reintegration in terms of sustainability (Black, Koser, Munk, Atfield, D’onofrio, \& Tiemoko, 2004), both at an individual level -psychosocial adaptation of the returnee to origin and personal success and welfare of the returnees and their families- (Ghosh, 2000; King, 2017); and in terms of community development - "contributions" from subjects upon return $^{5}$ - (Ghosh, 2000; Koser, 2000). In this sense, not only highly qualified migrants should be considered, but also the human capital accumulated from the experience abroad could contribute to the development of the community (Cobo, 2008). In any case, the skills should be recognised in origin for putting it in effective use (Ghosh, 2000).

Also, sustainable return could respond to macroeconomic and political indicators, attending to the role of the State in the management of return and reintegration (Black \& Gent, 2006). In this sense, several authors point out that usually the personal and family welfare, as well as the psychological issues, should be incorporated into the reintegration policies (King, 2017). For this, a policy recommendation should be to centre policy and programmes around an approach that

\footnotetext{
${ }^{4}$ Cassarino (2004) and Cobo (2008) are authors that are framed in the transnational perspective but that dialogue in their analysis with the networks approach, acquiring the social capital and the mobilisation of resources acquire special relevance.

${ }^{5}$ In this sense, not only highly qualified migrants should be considered, but also the human capital accumulated from the experience abroad could contribute to the development of the community (Cobo, 2008).
} 
recognises the importance of an optimal reintegration in terms of the economic, physical and social dimensions (Van Houte \& Davids, 2008).

In any case, for both destination and host countries, policies should recognise the several profiles and situations in which returnees are. As King (2000) remarks, the return migration and the reincorporation process to the society of origin could depend on different factors and on the type and nature of the return, such as the motives of the return, the time patterns, the timing of the return and the willingness of this migration. In this sense, González-Ferrer (2013) highlights that the states should develop different programmes at least according to three key criteria: the migrant's family situation, the duration of the stay abroad and the nature of the return (as an emergency -extremely vulnerable situations- or as a "possibility"). She also suggests that it could be wise to coordinate return programmes in the destination (pre-return actions) and host countries (post-return actions), so as to avoid duplicities and as to offer a more integral assistance.

For this reason, the aim of this paper is to review the return policies developed by Spain and Colombia, with the objective of attending to how the return management is posed from two territories involved in the same migration process ${ }^{6}$. Analysing the type of assistance offered, as well as the profiles of returnees that it considers, will allow us to see how the return migration is considered from both territories.

\section{Brief contextualisation of migration flows in Spain and from Colombia}

The economic recession has led to a disruption of flows in and out of Spain. Whereas the largest number of residential registrations of people from Latin America over the past two decades was recorded in $2007^{7}$, since the subsequent year it could be observed that the effects of the economic crisis have affected the migration trend over the last decade. Since 2008 the number of entries has started to decrease, while the number of exits, although to a lesser extent, is becoming even higher. From this dynamic it is observed that in 2012 the number of exits was higher than the number of entries, registering the country a negative migration balance. This shift takes place in a complex labour market, where the migrant population has deeply affected by job

\footnotetext{
${ }^{6}$ This is not to imply that there are only bi-directionality movements, but that people can pose a migration that includes third geographic spaces (Guarnizo \& Chaudhary, 2014).

${ }^{7}$ According to data from the main series since 1998 of residential registrations in the Spanish National Statistic Institute (SNSI, 2007).
} 
losses, with an unemployment rate of 39.1\% being recorded in 2011 (Colectivo Ioé, 2012).

However, data from 2014 show again a slight rise in residential registration over the previous year. Arrivals may respond to a "new migration", that is, people who had never migrated to Spain before. It should be taken into account that this can also involve people who had previously resided in the country and, after returning to their country of origin, have decided to resume the migration and go back to Spain. It is also important to point out that it is an error to link the residential deregistration with the return migration. In this sense, it is necessary to consider the re-migration from Spain to other countries, especially after a decade in which a significant number of Latin American people have reached a stable legal status in Spain by obtaining Spanish nationality or a residence permit (Recaño \& Jauregui, 2014).

Regarding the international migration process in Colombia, it is important to state its historical and generalised character. A greater dynamism is observed from the sixties and especially from the late nineties (Bedoya, 2014). There are three phases that mark the Colombian international migration, starting with Venezuela and the USA as major destinations in the sixties and seventies. The second phase takes place between the seventies and eighties, with Europe as the main destination of socio-economic elites, political refugees, intellectuals and $\operatorname{artists}^{8}$. Similarly, in the mid-eighties mainly Venezuela and also the USA are again listed as predominant destinations, in a scenario marked by rising unemployment and the decline in the GDP in the country (Actis, 2009).

Finally, from the second half of the nineties, where the context of violence is accentuated and the implementation of the neoliberal model has a strong negative impact on employment, the third exit abroad occurs, with a diversification of destinations being recorded. Some European and Latin American countries stand out at this time, as well as Canada, Japan and Australia (Ciurlo, 2015). Since 2000, Spain is drawn as the new preferred destination for Colombian migrants, with a diversification of profiles in terms of regional and social extraction being recorded at this stage (Guarnizo, 2006a). Due to the high migration to Spain, Colombians are constituted as a third group of non-EU foreigners in the country between 2000 and 2004, despite the visa requirement imposed by the Spanish government from 2002 until December 2015.

\footnotetext{
${ }^{8}$ Colombian migration to England also stands out in this period, as result of the call from the English government to recruit unskilled foreign labour (Guarnizo, 2008).
} 
In relation to the dynamics of return migration, although the lack of official data makes it impossible to know the extent of the phenomenon of migrants returning to Colombia, data from the 2005 Census and the National Survey on Migration and Remittances 2008-2009 (NSMR, 2009) ${ }^{9}$ indicate that for the period 2005-2008 most of the returnees came from the USA (32.4\%), Venezuela $(27.3 \%)$ and Spain $(16.4 \%)^{10}$. The profile identified by the survey is predominantly male and middle-aged, so it was people of working age. With regard to recent years, in a context of economic recession and tightening of immigration controls in the USA and other countries, new migration dynamics have arisen in this collective, with a reduction in migration intensity to certain countries, a growing re-migration to third destinations and greater return ${ }^{11}$-especially from Spain-, as well as the emergence of different currents (Mejía, 2012).

\section{Results. Return migration policies: the case of Spain and Colombia}

\subsection{Return policies developed from the host country: the case of Spain}

In the last decade, the European Union has undertaken the promotion of actions to encourage return both voluntary and forced return, emphasising especially the return of people in an irregular situation ${ }^{12}$. Among the initiatives promoted are the European Return Fund (FER), implemented in 2008-2013, and the current Fund for Asylum, Migration and Integration (FAMI) ${ }^{13}$, for the period 2014-2020. Both Funds refer to financing strategies for voluntary return/expulsion that Member States can develop. Based on Community legislation, Spain has launched, over the last decade and a half, three programmes for Assisted Voluntary Return. Two of them are intended for people experiencing extreme social vulnerability, and the third is aimed at individuals who have unemployment benefit (see Table 1).

The first action taken on return is the "Program for Voluntary Return of Social Attention", launched in 2003. The date on which it is launched does not respond to the

\footnotetext{
${ }^{9}$ Survey conducted in eighteen Colombian cities in four regions of the country with high out-migration (North, West Central, Bogotá and Valle) to returnees who returned before 2005 up until 2008. The NSMR estimated that by early 2009, 534,943 people had returned to Colombia.

${ }^{10}$ In 2005, the National Statistics Department estimates that the Colombian migrant population is concentrated mainly in the US (34.6\%), Spain (23\%) and Venezuela (20\%) (Echeverri \& Pavajeau, 2015).

${ }^{11}$ However, Mejía (2012), from the data collected in the NSMR, indicates that many people return as something temporary, especially those with dual nationality.

${ }^{12}$ In 2008 the European Parliament adopted the Return Directive 2008/115/EC on common standards and procedures in Member States for returning illegally staying third-country nationals. The legal text promotes the principle of voluntary return (as the result of an expulsion order) rather than forced return, the political initiative focusing on defining procedures for the deportation of people in an irregular situation.

13 The FER, established by Commission Decision 575/2007/EC is expressly revoked by Regulation $516 / 2014$ of the European Parliament and of the Council of 16 April 2014, by which FAMI is created.
} 
period of economic downturn; however, it does match the time when an increase in residential registrations of foreigners in the country started to be noticeable. However, figures show that the host programme had a limited impact in the first years of its implementation, with the biggest increase being experienced in 2009. Since the target profile of this initiative are people in a socially vulnerable situation, the programme contemplates almost exclusively humanitarian assistance from Spain, and lacks an explicit protocol to monitor migrants who has returned and being the process managed in many cases as a unilateral way. In this case, only the pre-return phase is considered, leaving the programme itself as a process of support to the preparation of the return and reincorporation process in origin.

However, in order to achieve a more sustainable return where it is contemplated as a complex migration process, the resolution of 14 May 2014 issued by the Migration Board $^{14}$ states that the institutions managing the programmes have to start from a strategy of networking with institutions in the country, either with the existence of a counterpart of such entity in the countries of origin -an essential prerequisite in the case of a business being developed in such country of origin, as will be discussed later- or in collaboration with other entities from the places to where the migrants return. It was thus established that entities should work in collaboration with the "One Stop Shops" project to support the voluntary return from Spain, Italy and Portugal to eight countries in Latin America ${ }^{15}$. This project is coordinated by the Organisation of Ibero-American States (OEI) together with the Spanish Ministry for Economy and Social Security (MEYSS $)^{16}$. The project offers support in the context of psychosocial, educational and labour issues, its key objective being networking aiming to create One Stop Shops for information and advice, in order to overcome the dispersion of services to returnees ${ }^{17}$.

The "Productive Return Program" was launched in Spain in 2010, which proposes the grant of financial assistance for the creation of micro-enterprises in the countries of origin, with aspects of post-return phase being taken into account and

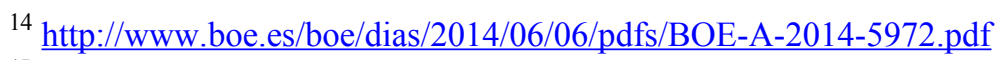

${ }^{15}$ The countries covered are Peru, Bolivia, Colombia, Brazil, Ecuador, Paraguay, Chile and Uruguay.

${ }^{16}$ The project was promoted for 2012-2014, currently being in the active second portion thereof for the period 2014-2016 (http://www.oei.es/ventanillasunicas/) ).

${ }^{17}$ As background to this initiative is the PTRSI project "Euro-Latin American vocational training system for the return and reintegration in Latin America", also led by the OEI during 2012-2013 (http: // www. oei.es/70cd/sistemaeurolatinoamericanodefinitivoespol.pdf). Other projects that are based on approaches to the return on this line are collected in Parella \& Petroff (2014).
} 
requiring -from 2012- the bilateral management by the entity in Spain and its counterpart in the country of origin. It is assumed, therefore, that the return requires planning of the new migration and reintegration process in the country of origin. In this sense, the FAMI puts the greatest emphasis on the strengthening of actions that contribute to the reintegration of subjects in the production or wage labour market. However, there is a lack of joint participation between entities in Spain and institutions in the countries of origin, with the transnational nature of the programmes often being negligible.

On the other hand, the "Additional Aid Program to the Cumulative advanced payment of unemployment benefit to non-EU foreign workers" (APRE), was implemented in 2008 with the onset of the economic downturn. It includes the possibility of cumulative payment of unemployment benefit to those in a regular situation. The intervention from Spain is limited to the delivery of the accumulated contributions, with the assistance contemplated in the programme being unilateral and administrative in nature. While it is positive that subjects can have an economic capital that can be used in their post-return phase, the absence of government involvement in this type of return does seem to refer to an exclusively labour logic, where it seems that countries receiving of migrants "facilitate the repatriation as a form of decompression of their societies and labour markets" (Mármora, 2002: 301).

Additionally, while the operation and objectives of the programmes differ, all three initiatives have a number of common requirements that applicants must meet to be eligible for them. First, the migrants may not be in possession of the Spanish nationality. They should have remained in Spain a minimum of six months and state their intention to return voluntarily. In addition, prior to the return, the migrant has to deliver the residence permit, being forbidden to enter the country in order to reside or carry out productive activities for three years ${ }^{18}$, and thus denying possible circular approach to the return. In this sense, some authors have pointed out that the policies implemented by the receiving countries are usually instruments of management and regulation of migration flows, often responding to an ejector tool (Cassarino, 2008).

However, the change contemplated in the FAMI with respect to the FER is interesting. While the former states as beneficiary persons both in regular and irregular

\footnotetext{
${ }^{18}$ The legislation provides the possibility of recovering the Long Term Residence Permit, respecting time of residence, upon completion the period of commitment not to return. Those subjects who delivered their Temporary Resident Card will have a preferential right to join the contingent of non-community foreign workers, at the expense of those who deliver the documentation required for this purpose.
} 
administrative situation, the FER was aimed exclusively to those foreigners who have ceased to fulfil the conditions of entry and residence in the country they migrate to. Given this distinction, the Spanish government distinguished two sides within the "Program for Voluntary Return of Social Attention" and the "Productive Return Program", one aimed at people in an irregular situation (funded by the MEYSS and FER) and one aimed at persons in a regular situation (financed exclusively by the MEYSS). At present, as indicated, the FAMI does not do such differentiation, even if their budget can be distributed, according to the needs and preferences of countries, between various areas of activity, while the FER supported measures related only to return, both voluntary or as the result of an expulsion.

In relation to the profiles of migrants considered by the return programmes, although the programmes are directed especially to people in situations of economic vulnerability, they do not make any distinction as to gender, age, family situation, duration of the migration experience, etc., thus ignoring the various situations and needs of the potential returnees. Although it is clear that such programmes are taking place in a context of economic recession in Spain, the type of approach made from the programmes also omits the vast array of factors that may influence decision-making, linking return (and the need to receive orientation and support for the return to the origin country) to purely macroeconomic issues that have generated situations of vulnerability. 
Table 1. Actions before the return driven from Spain

\begin{tabular}{|c|c|c|c|c|}
\hline Action & Description & Recipients & $\begin{array}{l}\text { Responsible } \\
\text { body }\end{array}$ & $\begin{array}{c}\text { Analytical } \\
\text { dimensions }\end{array}$ \\
\hline $\begin{array}{l}\text { Program for } \\
\text { Voluntary } \\
\text { Return of Social } \\
\text { Attention (2003 -) }\end{array}$ & $\begin{array}{l}\text { Economic aid: travel } \\
\text { fare payment and } 450 € \\
\text { for installation } \\
\text { Assistance: } \\
\text { information services, } \\
\text { psychosocial support } \\
\text { and counseling }\end{array}$ & $\begin{array}{l}\text { Non-EU foreigners who } \\
\text { have resided in Spain for } \\
\text { at least six months, and } \\
\text { which are at particularly } \\
\text { vulnerable social } \\
\text { situation }\end{array}$ & $\begin{array}{l}\text { Promoted by: } \\
\text { Ministry of } \\
\text { Employment and } \\
\text { OIM } \\
\text { Managed by: } \\
\text { MEYSS } \\
\text { Funded by: } \\
\text { MEYSS and } \\
\text { FAMI }\end{array}$ & $\begin{array}{l}\text { Humanitarian } \\
\text { assistance } \\
\text { offered to } \\
\text { vulnerable } \\
\text { profiles. } \\
\text { Unilateral } \\
\text { management } \\
\text { with semi- } \\
\text { permanent } \\
\text { return. }\end{array}$ \\
\hline $\begin{array}{l}\text { Productive } \\
\text { Return } \\
\text { Program (2010 -) }\end{array}$ & $\begin{array}{l}\text { Economic aid: a } \\
\text { maximum of } 5,000 € \text { for } \\
\text { the development of a } \\
\text { business in the country } \\
\text { of origin. Payment of } \\
\text { travel fare. } \\
\text { Counseling: Training } \\
\text { for the development of } \\
\text { a business plan } \\
\text { Post-return support: } \\
\text { follow-up after the } \\
\text { return and advice in } \\
\text { implementing the } \\
\text { business }\end{array}$ & $\begin{array}{l}\text { Non-EU foreigners who } \\
\text { have resided in Spain for } \\
\text { at least six months, and } \\
\text { which are at particularly } \\
\text { vulnerable social } \\
\text { situation. It is a } \\
\text { requirement to present a } \\
\text { viable business project } \\
\text { to be developed in the } \\
\text { country of origin }\end{array}$ & $\begin{array}{l}\text { Promoted and } \\
\text { managed by: } \\
\text { MEYSS } \\
\text { Funded by: } \\
\text { MEYSS and } \\
\text { FAMI }\end{array}$ & $\begin{array}{l}\text { Preparation } \\
\text { and } \\
\text { reintegration } \\
\text { orientation for } \\
\text { "productive" } \\
\text { returns } \\
\text { migrants. } \\
\text { Bilateral } \\
\text { intervention } \\
\text { with semi- } \\
\text { permanent } \\
\text { return. }\end{array}$ \\
\hline $\begin{array}{l}\text { Additional Aid } \\
\text { Program to the } \\
\text { Cumulative } \\
\text { advanced payment } \\
\text { of unemployment } \\
\text { benefit (APRE) } \\
(2008 \text {-) }\end{array}$ & $\begin{array}{l}\text { Administrative } \\
\text { management: } \\
\text { accumulated payment } \\
\text { of unemployment } \\
\text { benefit. Delivery of } \\
40 \% \text { of the benefit at } \\
\text { the moment of } \\
\text { registration and } \\
\text { collection of the } \\
\text { remaining } 60 \% \text { upon } \\
\text { arrival at the country of } \\
\text { origin }\end{array}$ & $\begin{array}{l}\text { Non- EU Foreigners in } \\
\text { regular situation whose } \\
\text { country of origin has } \\
\text { signed a bilateral } \\
\text { agreement with Spain on } \\
\text { Social Security } \\
\text { Being entitled to the } \\
\text { payment of } \\
\text { unemployment benefits }\end{array}$ & $\begin{array}{l}\text { Promoted and } \\
\text { managed by: } \\
\text { MEYSS } \\
\text { Funded by: } \\
\text { MEYSS and } \\
\text { FAMI }\end{array}$ & $\begin{array}{l}\text { Informative } \\
\text { advice to } \\
\text { unemployed } \\
\text { migrants in } \\
\text { Spain. } \\
\text { Unilateral } \\
\text { management } \\
\text { and semi- } \\
\text { permanent } \\
\text { return. }\end{array}$ \\
\hline
\end{tabular}

Source: Elaborated by the author

\subsection{Return policies developed from the country of origin: the case of Colombia}

The first actions designed by the Colombian government aimed at citizens abroad coincide with the first phase of the Colombian migration wave. The Law 30.572 of 1961, by which the vote of Colombians living abroad for the presidential election is authorised, in this regard represents a precedent. A decade later, coinciding with the migration of Colombians -especially professionals- to the USA, the government developed the "Return Program for Professionals and Technicians" (1972), a measure 
that was valid for one year and provides tax benefits for highly qualified Colombians (Sánchez \& Hermida, 1983). With the exception of these first actions, it is not until the nineties (when migration flows start to see an acceleration) that the government begins to incorporate its migrant population to the national project (Guarnizo, 2006b), providing fellow citizens abroad with a series of constitutional rights.

In the following years various state initiatives to promote linkages between the State and Colombians abroad were developed ${ }^{19}$, such as the "Colombia Nos Une" Programme (CNU) (2004). This programme aims to promote ties with the diaspora, and raises the relevance of designing a migration policy to meet the needs of this population. However, some authors refer to the advantages for the State in the incorporation of migrants into the political agenda in a scenario where the Colombian migration is particularly relevant at a quantitative level, and where remittances, the electoral potential of migrants in the country and the role of migrant actors in the image of Colombia are perceived as having an undeniable value for the country (Ardila, 2009; Clavijo, 2014).

In terms of return, seen as the main line of work of the CNU Programme, the government emphasises the need to develop a "Return Plan" to guide returnees to achieve a dignified and productive integration. Additionally, the "Integral Migratory Policy" (2009) was developed, with the aim of achieving an effective and coordinated care to the Colombian population abroad and foreigners residing in Colombia (NCESP, 2009). In 2011 the National Migration System (Law 1465 of 2011) was created, which aims to support the government in the design and implementation of public policies and actions aimed at strengthening ties between the State and Colombians residing abroad, as well as the development and implementation of the "Return Plan" (Hinojosa, 2011) ${ }^{20}$.

As part of these actions, and in a context marked by the economic recession in Spain and the USA, the government developed several programmes aimed at promoting the return and promulgated the Law 1565 of 2012 (see Table 2). Among those initiatives driven, those aiming to provide care and counselling to returnees ("Positive Return Plan"), such as tax benefits for returning subjects (Law of Return) stand out. Furthermore, existing return programmes refer to the incorporation into the workplace, either through the development of a microenterprise -taking into account a period of

\footnotetext{
19 They develop further rules related to the institutional organisation and legal tools to address the diaspora. See NCESP (2009: 2-7).

${ }^{20}$ However, the Law 1465 of 2011 does not include the regulation to allow the implementation of many of the actions contemplated, having been ineffective with regards to practical terms of return.
} 
business training and entrepreneurship-, or through promoting recruitment via postdoctoral stays. However, despite these specific initiatives, in practice the instruments of support for the reincorporation process have not been designed ad hoc for the returned population, but are services offered to the whole of the Colombian population. In relation to the profiles object of the initiatives, it should be noted that although the legislation establishes a typology of returnees, recognising a variety of profiles that require the application of differentiated actions, in practice a given population is contemplated, such as productive profiles and highly qualified individuals ${ }^{21}$.

In terms of management, programmes are primarily focused on the post-return phase of the process, with the intervention devolving upon the local actor. It is a fact, however, that the "Plan for the Productive Return from Spain" (2012) does contemplate an intervention in the pre-return phase where the potential returnee is counselled in the development of a business plan to be developed in Colombia after the return. However, the actions taken from Spain were developed by a private entity, leaving aside the collaboration or coordination between countries at the institutional level. Finally, with regards to temporary approaches before the return, the Colombian government does not restrict the mobility of returnees, omitting any requirement to stay in the country. Therefore, the starting point is a conception of return that recognises the circularity of the migration process and the understanding that the return to the country of origin does not have to be permanent, thus permitting circular/pendulum and potential future remigration.

\footnotetext{
${ }^{21}$ In this regard, the requirement marked by the Agreement 000102013 from SENA of being in possession of a professional or technical degree to access the Entrepreneur Fund of SENA evidences the selectivity of actions.
} 
Table 2. Actions before the return driven from Colombia

\begin{tabular}{|c|c|c|c|c|}
\hline Action & Description & Recipients & $\begin{array}{c}\text { Responsible } \\
\text { body }\end{array}$ & $\begin{array}{l}\text { Analytical } \\
\text { dimensions }\end{array}$ \\
\hline \multirow[t]{2}{*}{$\begin{array}{l}\text { Positive Return } \\
\text { Plan (2009-2012) }\end{array}$} & $\begin{array}{l}\text { Accompaniment and } \\
\text { recognition of the } \\
\text { experiences and } \\
\text { knowledge acquired } \\
\text { abroad. }\end{array}$ & $\begin{array}{l}\text { Colombians who have } \\
\text { resided at least } 12 \\
\text { months abroad and have } \\
\text { returned after June } \\
2010 .\end{array}$ & \multirow[t]{2}{*}{$\begin{array}{l}\text { Implemented } \\
\text { by: Ministry } \\
\text { of Foreign } \\
\text { Affairs. }\end{array}$} & \multirow[t]{2}{*}{$\begin{array}{l}\text { Diverse profiles, } \\
\text { but no definite } \\
\text { concrete actions or } \\
\text { reintegration } \\
\text { programmes. } \\
\text { Unilateral } \\
\text { management with } \\
\text { non-temporal } \\
\text { obligation. }\end{array}$} \\
\hline & $\begin{array}{l}\text { Agreement for the } \\
\text { creation of services at } \\
\text { regional level to } \\
\text { facilitate the } \\
\text { reintegration of } \\
\text { returnees: Centres of } \\
\text { Reference and } \\
\text { Opportunities for } \\
\text { Foreign Returnees } \\
\text { (CRORE). Currently in } \\
\text { Bogotá City and } \\
\text { Department of } \\
\text { Risaralda. }\end{array}$ & $\begin{array}{l}\text { Colombians returning to } \\
\text { regions where CRORE } \\
\text { are present. }\end{array}$ & & \\
\hline $\begin{array}{l}\text { Law } 1565 \text { of } \\
2012(2012-)\end{array}$ & $\begin{array}{l}\text { Incentives in tax and } \\
\text { financial areas } \\
\text { Typology of returnees: } \\
\text { conflict victims, } \\
\text { vulnerable people, } \\
\text { highly skilled returnees } \\
\text { and productive return. } \\
\text { Contemplates aspects of } \\
\text { the military situation, } \\
\text { and access to family } \\
\text { compensation funds }\end{array}$ & $\begin{array}{l}\text { Colombians who have } \\
\text { resided abroad for at } \\
\text { least } 3 \text { years; }\end{array}$ & $\begin{array}{l}\text { Implemented } \\
\text { by: Ministry } \\
\text { of Foreign } \\
\text { Affairs and } \\
\text { Ministry of } \\
\text { Finance and } \\
\text { Public Credit }\end{array}$ & $\begin{array}{l}\text { Diverse profiles } \\
\text { considered, but no } \\
\text { definite concrete } \\
\text { actions or } \\
\text { reintegration } \\
\text { programmes to any } \\
\text { of them. } \\
\text { Unilateral } \\
\text { management with } \\
\text { non-temporal } \\
\text { obligation. }\end{array}$ \\
\hline $\begin{array}{l}\text { Plan for the } \\
\text { Productive } \\
\text { Return from } \\
\text { Spain (2012) }\end{array}$ & $\begin{array}{l}\text { Instruction and advice } \\
\text { on entrepreneurship and } \\
\text { the business sector to } \\
300 \text { Colombian } \\
\text { residents in Spain. } \\
\text { Support and access to } \\
\text { seed capital from the } \\
\text { SENA Entrepreneur } \\
\text { Fund. }\end{array}$ & $\begin{array}{l}\text { University professionals } \\
\text { or people with a } \\
\text { technical degree, who } \\
\text { wish return and develop } \\
\text { a productive project. }\end{array}$ & $\begin{array}{l}\text { Funded by: } \\
\text { Government } \\
\text { of Colombia } \\
\text { Implemented } \\
\text { by: Ministry } \\
\text { of Foreign } \\
\text { Affairs, } \\
\text { SENA and } \\
\text { INCYDE }\end{array}$ & $\begin{array}{l}\text { Reintegration } \\
\text { orientation for } \\
\text { highly qualified } \\
\text { returnees who want } \\
\text { to develop a } \\
\text { productive project. } \\
\text { Bilateral } \\
\text { intervention with } \\
\text { non-temporal } \\
\text { obligation. }\end{array}$ \\
\hline $\begin{array}{l}\text { "Es tiempo de } \\
\text { Volver" (2014) } \\
\text { Programme }\end{array}$ & $\begin{array}{l}\text { Incorporation, through } \\
\text { postdoctoral stays } 200 \\
\text { doctors in the } \\
\text { Colombian academic } \\
\text { and business sector. }\end{array}$ & $\begin{array}{l}\text { Colombians with PhD } \\
\text { degrees acquired } \\
\text { abroad, who live abroad } \\
\text { or have returned in the } \\
\text { last two years. }\end{array}$ & $\begin{array}{l}\text { Funded by: } \\
\text { Government } \\
\text { of Colombia } \\
\text { Implemented } \\
\text { by: } \\
\text { COLCIENCI } \\
\text { AS }\end{array}$ & $\begin{array}{l}\text { Informative advice } \\
\text { to highly qualified } \\
\text { returnees. } \\
\text { Unilateral } \\
\text { management with } \\
\text { non-temporal } \\
\text { obligation. }\end{array}$ \\
\hline
\end{tabular}

Source: Elaborated by the author 


\section{Conclusions}

The review and analysis of the actions and programmes developed by the Spanish and Colombian government show the growing interest of both countries in promoting return, although the objectives of each of the parties show some differences. Regarding the type of initiatives developed in Spain, some efforts to reduce the purely welfare related nature of the actions are observed. The importance at the discursive level of the need to accompany the returnee in the country of origin stands out, an example of which are the "One Stop Shops", used in cases where the return is handled through the Social Care programme. It is recognised that return migration is not a simple act of coming back to the birth country, but a process composed of interconnected phases where there is a preparation and reincorporation to the country of origin, as the transnational perspective points out. The aim is to overcome a more classical view of the return process, surpassing a reflection that simply links migration with a rational decision on economic costs and benefits.

However, the APRE continues to respond to a simple "Pay-to-Go" programme, where unemployed migrants are encouraged to return to the country of origin through economic incentives, ignoring any process of support for the reinstatement back home. Thus, it is identified more as a programme to ease tension in the Spanish labour market, than as an initiative for assistance during the return. However, it must be acknowledged that the recognition by FAMI of people in regular situation wishing to benefit from the programmes is a significant step forward, disregarding the expulsion approaches of the previous Fund. However, the conception of return as the end of the cycle, restricting the return to Spain for three years, denies the dynamic and multidirectional vision of migratory mobility. In relation to the profiles that are the object of the programmes, although they aim to tend to those people who are especially hit by the economic crisis in Spain, it is assumed that the people who return are a group with homogenous needs. Different processes of return are ignored according to the country of return, time abroad, age, gender, family situation, etc. They are key elements to consider when mobilising resources for return and also to achieve optimal reincorporation processes, as pointed out by King (2000) and González-Ferrer (2013).

Moreover, the action of the Colombian government, mainly focused on the postreturn phase, stands out, where the need to address and guide a variety of profiles of returnees recognised by the law is contemplated and where specific actions to promote the reintegration focus on implementing a business or return to the labour market for 
highly qualified profiles. On the other hand, although the development of a Law of Return is an important step in migration policies, the fact that it relies on economic incentives makes it a law for tax exemption rather than an effective instrument of accompaniment and reinstatement. The establishment of a link between return, economic development based on investment of economic capital, the entrepreneurial skills of returnees, and the application of human capital is observed. Thus, while the recognition of the capital acquired during the migratory experience is a positive development, it is still necessary to develop measures to evaluate the accumulated assets and to promote their application upon return.

It is also advisable for programmes to take into account the possible employment status inconsistency that many migrants face abroad, and which may be a handicap when it comes to joining the qualified labour market in Colombia. In addition, it would need to be taken into account that the countries (like Spain) from which people are returning have suffered a severe economic recession, and that not all returnees have the necessary economic resources at their disposal and, therefore, need more attention and guidance. Thus, the commitment to self-employment (where economic capital is required for start-up) to the detriment of actions that promote the return to the salaried labour market.

As a general conclusion, it is observed how targeting a specific returnee's profiles results in the absence of other mechanisms of reintegration that contemplate the diversity of needs and characteristics of returnees. In this sense, Echeverri and Pavajeu (2015) highlight the weak impact of Colombian migration policies due to a lack of effective response initiatives developed taking into account the return experiences of returnees. The absence of specific programmes for the heterogeneity of returns evidence a critical gap in the performance of the government, which seems to respond to a political rationality (Moncayo, 2011) to the detriment of effective attention to the migration situation in the country. The focus of activity lies therefore in the recovery of the "ideal returnee" and the contributions it can make at a productive and economic level in the country. Therefore, an optimal reintegration policy will be that which contemplated a sustainable reincorporation process from a labour/economic area, but also from the psychological and social dimensions.

Regarding the type of management carried out, in the case of productive return programmes, the aim was to involve the stakeholders in both scenarios in the two countries. However, it would be interesting to have a joint and coordinated initiative, 
which could optimise resources and streamline the process of preparation and return. In this sense, it would be necessary that both destination and origin countries considered the return migration as a complex process composed of interconnected stages (pre- and post-return). A transnational approach to the management of the return migration would ensure a better preparation of the process taking into account the resources available at destination and the necessary capitals at origin. Also, in understanding return migration as a new movement (and not as the simple act of "coming back home" -in spite of the possible transnational networks and practices that have taken place-), it is necessary to consider the reintegration process in all its dimensions (economic, psychological and social). On the other hand, the consideration of heterogeneous profiles of returnees (beyond identifying people in situations of economic vulnerability) is essential for achieving a sustainable return (at the individual and community development levels), overcoming the idea that only macroeconomic factors are considered in the return decision-making.

Nevertheless, considering the objectives of policies depending on the country and the different conception in terms of temporality, it appears complex to develop an action as a result of the sum of synergies, where tangible and intangible resources from both sides could be relied upon and the starting point would be a joint and comprehensive view of migration.

\section{References}

Actis, W. (2009). La migración colombiana en España: ¿salvados o entrampados?. Revista de Indias, LXIX, 245, 145-170.

Ardila, G. (ed.), (2006). Colombia: Migraciones, transnacionalismo y desplazamiento. Bogotá: Centro de Estudios Sociales. Universidad Nacional de Colombia. Facultad de Ciencias Humanas.

Amelina, A., \& Faist, T. (2012). De-naturalizing the national in research methodologies: key concepts of transnational studies in migration. Ethnic and Racial Studies, $35(10), 1707-1724$

Ammasari, S., \& Black, R. (2001). Harnessing the potential of migration and return to promote development. Geneva: IOM.

Basch, L., Glick Shiller, N., \& Szanton Blanc, C. (1994). Nations unbound. Transnational projects, postcolonial predicaments and deterritorialized nationstates. Pensylvania: Gordon and Breach Science Publishers. 
Bauböck, R. (2003). Toward a political theory of migrant transnacionalismo. International Migration Review, 37(3).

Black, R., \& Gent, S. (2006). Sustainable return in post-conflict contexts. International Migration, 44(3), 15-38.

Black, R., Koser, K., Munk, K., Atfield, G., D’onofrio, L., \& Tiemoko, R. (2004). Understanding voluntary return. Home Office Online Report 50/04. Retrieved from http://sro.sussex.ac.uk/11041/

Bedoya, M. (2014). El papel de las políticas públicas de migración y retorno en Colombia en el marco de la crisis económica mundial: los casos del Eje Cafetero, Cali, Medellín y Bogotá. Estudios Políticos, 46, 79-99.

Cassarino, J. P. (2004). Theorising return migration: The conceptual approach to return migrants revisited. In P. de Guchteneire (dir.), Managing migration and diversity in the Asia Pacific Region and Europe. International Journal on Multicultural Societies, 6(2), 253-279.

Cassarino, J. P. (2008). The conditions of modern return migrants. editorial introduction. International Journal on Multicultural Societies, 10(2), 95-105.

Castles, S. (2006). Guestworkers in Europe: A Resurrection? International Migration Review, 40(4), 741-766.

Ciurlo, A. (2015). Nueva política migratoria colombiana: El actual enfoque de inmigración y emigración. Revista Internacional de Cooperación y Desarrollo, 2(2), 205-242.

Clavijo, J. (2014). La Política migratoria colombiana en el periodo 2002 -2010: el programa Colombia nos une $(C N U)$. Córdoba: Ed. Centro de Estudios Avanzados, Colección Tesis.

Cobo, S. (2008). ¿Cómo entender la movilidad ocupacional de los migrantes de retorno? Una propuesta de marco explicativo para el caso mexicano. Estudios Demográficos y Urbanos, 23(1), 159-177.

Colectivo Ioé (2012). Impactos de la crisis sobre la población inmigrante. Madrid: OIM.

Cortes, G. (2009). Migraciones, construcciones transnacionales y prácticas de circulación. Un enfoque desde el territorio. Párrafos Geográficos, 8(1), 35-53.

De Haas, H., \& Fokkema, T. (2010). Intra-household conflicts in migration decision making: return and pendulum migration in Morocco. Population and Development Review, 36, 541-561. 
Dumon, W. (1986). Problems faced by migrations and their family members, particulary second generation migrants, in returning to and reintegrating into their countries of origin. International Migration, 24, 113-128.

Echeverri, M., \& Pavajeau, C. (2015). El sujeto del retorno en Colombia. Entre políticas, leyes y trayectorias de resistencia de la población migrante retornada. Mondi Migranti, 3, 83-103.

Ghosh, B. (2000). Return migration: reshaping policy approaches. In B. Ghosh (ed.). Return migration: Journey of hope or despair? (pp. 181-226). Geneva: IOM.

González-Ferrer, A. (2013). Retorno y reintegración de los migrantes latinoamericanos en Europa. In Izquierdo, A. (ed.). Propuestas para vincular las políticas de migración y empleo (pp. 53-89). Madrid: FIIAPP.

Gmelch, G. (1980). Return migration. Annual Review of Anthropology, 9, 135-159.

Guarnizo, L. (2006a). El estado y la migración global colombiana. Migración y desarrollo, 6, 79-101.

Guarnizo, L. (2006b). Migración, globalización y sociedad: teorías y tendencias en el siglo XX. In G. Ardila (ed.). Colombia: migraciones, transnacionalismo y desplazamiento. Bogotá: Universidad Nacional de Colombia. Facultad de Ciencias Humanas. Colección Centro de Estudios Sociales (CES).

Guarnizo, L. (2008). Londres Latina: La presencia colombiana en la capital británica. México D.F.: Universidad Autónoma de Zacatecas/Miguel Ángel Porrúa.

Guarnizo, L., \& Chaudhary, A. (2014). Determinants of transnational political engagement among Dominican and Colombian migrants in Southern Europe. IMI Working Papers Series 2015, 112.

Hinojosa, A. (2011). Análisis descriptivo de las instituciones responsables de la gestión de las políticas migratorias en Bolivia, Colombia, Ecuador y Perú. Madrid: FIIAPP.

King, R. (2000). Generalizations from the history of return migration. In B. Ghosh (ed.). Return Migration: Journey of Hope or Despair? (pp. 7-55). Geneva: IOM.

King, R. (2017). Exploring the multiple complexities of the return migrationpsychosocial wellbeing nexus. In Z. Vathi \& R. King (ed.). Return migration and psychosocial wellbeing. Discourses, policy-making and outcomes for migrants and their families. London: Routledge. 
Koser, K. (2000). Return, readmission and reintegration: changing agendas, policy frameworks and operational programmes. In B. Ghosh (ed.). Return migration: Journey of hope or despair? (pp. 57-99). Geneva: IOM

Levitt, P., \& De la Dehesa, R. (2003). Transnational migration and a redefinition of the state: variations and explanations. Ethnic and Racial Studies, 26(4), 587-611.

Levitt, P., \& Glick Schiller, N. (2004). Transnational perspectives on migration: conceptualizing simultaneity. International Migration Review, 38(3), 1002-1039.

Massey, D., \& Espinosa, K. (1997). What's driving Mexico-U.S. migration? A theoretical, empirical, and policy analysis. American Journal of Sociology, 102, 939-999.

Mármora, L. (2002). Las politicas de migraciones internacionales. Buenos Aires: Paidós.

Mejía, W. (2012). Colombia y las migraciones internacionales. Evolución reciente y panorama actual a partir de las cifras. Revista Interdisciplinar da Mobilidade Humana, REMHU, 20, 39.

Mejía, W., \& Castro, Y. (2012). Retorno de migrantes a la Comunidad Andina. Bogotá: Fundación Esperanza.

Moncayo, M. I. (2011). Políticas de retorno en América Latina: Miradas. Andina Migrante, 10, 2-10.

NCESP, National Council of Economic and Social Policies (2009). Documento 3603, Politica Integral Migratoria. Bogotá: Departamento Nacional de Planeación.

NSMR, National Survey on Migration and Remittances (2009). Encuesta Nacional 2008 - 2009, Resultados Generales de Migraciones y Remesas. Bogotá: Fundación Esperanza.

Papademetriou, D. G., Sumption, M., \& Terrazas, A. (2010). Migration and immigrants two years after the financial collapse: where do we stand? Report for the BBC World Service. Washington D.C.: Migration Policy Institute. Retrieved from https://www.migrationpolicy.org/research/migration-and-immigrants-two-yearsafter-financial-collapse-where-do-we-stand.

Parella, S., \& Petroff, A. (2014). Migración de retorno en España: salidas de inmigrantes y programas de retorno en un contexto de crisis. In J. Arango; D. Moya y J. Oliver (dir.), Inmigración y emigración: mitos y realidades. Anuario de Inmigración en España. Barcelona: CIDOB 
Parella, S., Petroff, A., Speroni, T., \& Piqueras, C. (2017). Social Suffering and return migrations: a conceptual proposal. Revista Apuntes, 81 (in press).

Parella, S., Petroff, A., Piqueras, C., \& Aiello, E. (2015). La gestión de la migración de retorno en los Países Andinos. Mondi Migranti, 3, 123-142.

Portes, A. (2005). Convergencias teóricas y evidencias empíricas en el estudio del transnacionalismo de los inmigrantes. Migración y desarrollo (México), 4, 2-19.

Portes, A., Escobar, C., \& Walton, A. (2006). Organizaciones transnacionales de inmigrantes y desarrollo: un estudio comparativo. Migración y Desarrollo, 3-44.

Portes, A., Guarnizo, L. E., \& Landolt, P. (1999). The study of transnationalism: pitfalls and promise of an emergent research field. Ethnic and Racial Studies, 22(2), 217 237.

Recaño, J., \& Jáuregui, J. (2014). Emigración exterior y retorno de latinoamericanos desde España: una visión desde las dos orillas (2002-2012). Notas de Población, 99, 177-240.

Rivera, L. (2009). “¿Quiénes son los retornados? Apuntes sobre el Migrante retornado en México contemporáneo". Ponencia presentada en la IV Reunión del Grupo de Trabajo Migración, Cultura y Políticas del Consejo Latinoamericano de Ciencias Sociales (CLACSO): La construcción social del migrante. Reflexiones desde América Latina y El Caribe. Ciudad de Guatemala, Guatemala.

Sánchez, J., \& Hermida, E. (1983). El éxodo de profesionales con estudios superiores en los Estados Partes en el Convenio Regional de Convalidación de Estudios, Títulos y Diplomas de Educación Superior en América Latina y el Caribe. Estudios y documentos de educación. Nueva serie, 45.

Sinatti, G. (2011). "Mobile transmigrants" or "unsettled returnees"? Myth of return and permanent resettlement among Senegalese migrants. Population, Space and Place, 17(2), 153-166.

Smith, R. C. (1999). Reflexiones sobre la migración, el Estado y la constitución, durabilidad y novedad de la vida transnacional. In G. Mummert (ed.). Fronteras Fragmentadas (pp. 55-86). Zamora: Colegio de Michoacán-CIDEM.

SNSI, Spanish National Statistics Institute (2007). Immigration National Survey. Madrid: Instituto Nacional de Estadística.

Stark, O. (1991). The migration of labour. Cambridge: Brasil Blackwell.

Solé, C., Parella, S., Sordé, T., \& Nita, S. (2016). Impact of circular migration on human, political and civil rights - A global perspective. New York: Springer. 
Todaro, M. (1969). A model of labor migration and urban unemployment in less developed countries. The American Economic Review, 59, 138-148.

Sánchez Trigueros, C., \& Fernández Collados, M. B. (2010). Retorno voluntario de inmigrantes. Trabajo: Revista andaluza de relaciones laborales, 23, 137-158.

Van Houte, M., \& Davids, T. (2008). Development and return migration: from policy panacea to migrant perspective sustainability. Third World Quarterly, 29(7), 1411-1429.

Wimmer, A., \& Glick Schiller, N. (2002). Methodological nationalism and beyond: nation-state building, migration and the social sciences. Global Networks, 2(4), 301-334. 